\title{
EN BILLEDBOG FRA GEORGIAS BARNDOM
}

\author{
AF
}

\section{Kristian HvidT}

$\mathrm{D}$ et er historieskriverens kunst at skildre begivenheder med ord. Men når han skal beskrive tilstande $i$ fortiden, kommer han ofte $\mathrm{i}$ bekneb - ord bliver let fattige, når prosaikere skal skildre naturen og menneskemængder. Så ser historieskriveren sig om efter billedstof og opdager, at her rinder kilderne betydeligt mere sparsomt end de skrevne. Lykkelig er derfor den historieskriver, der er så heldig at finde en kunstners skitsebog, hvor han har nedfældet, hvad han har set, uden forsøg på at besmykke hvad ojnene så.

Det er en sådan skitsebog, der i mere end halvandet hundrede år har ligget i Det kgl. Biblioteks håndskriftsamling. Her findes et halvt hundrede tegninger og akvareller, der giver et virkelighedstro kig ind i en fjern verden i i 73orne. Tegningerne hører sammen med begivenheder dengang, der nok ikke er nævnt $i$ almindelige verdenskroniker, en dråbe i det historiske hav - der dog afspejler vide perspektiver i både tid og rum. Når disse billeder, som indgår i et'arkiv i Ny kgl. Samling $5654^{\circ}$, har fảet lov at ligge uantastet hen, skyldes det, dels at de i sin tid er blevet henlagt under en ret intetsigende betegnelse, ${ }^{1}$ ) dels at de egentlig intet har med Danmark at gøre, bortset fra at de har endt deres lange rejse her. Det skyldes da også nærmest en tilfaldighed, at billederne er kommet mig i hænde og har begejstret mig som et enestående kildemateriale til belysning af Amerikas tidlige historie. Det er et sporgsmål for sig, hvordan dette arkiv, der belyser en kolonisationshistorie, som fører os fra Østrig til England og derfra til staten Georgia i Amerika, egentlig cr havnet i København. Forinden denne snirklede historie omtales, må jeg dog fortalle noget om sagens kerne: koloniseringen af staten Georgia i det sydøstlige USA.

I forrige århundrede skrev den engelske historiker John Robert Seeley de berømte ord, at det engelske kolonivælde for 1800 blev opbygget ,in 
a fit of absence of mind". Hele verden lo og tog ved lære af denne vittige konklusion. Der var megen sandhed indeholdt $\mathbf{i}$ den - Englands politik under Walpole's og Pitt's ledelse var ,trade, not empire”, og grundlæggelsen af de forste amerikanske kolonier faldt $i$ den engelske konges hænder, fordi hans undersåtter ikke udholdt det kirkelige regime i moderlandet. Men der var dog undtagelser fra Seeley's regel, og her er grundlæggelsen af staten Georgia nok den vigtigste - det var en virkelig planlagt kolonidannelse, hvori der naturligvis også indgik stærke kommercielle interesser, „empire and trade". Den vigtigste og langt den mest indbringende handelsrute i i 6oo-tallet og forste halvdel af det folgende århundrede skyldtes den såkaldte trekanthandel. Skibene sejlede fra England med våben, krudt og brogede tekstiler til Afrika, hvor disse varer ombyttedes med negerslaver, der bragtes til Vestindien. Her solgtes slaverne, og skibene blev ladet med bl.a. sukker og tobak, som siden solgtes i Europa. I begyndelsen af I 7 oo-tallet flyttedes tyngdepunktet fra Vestindien ind på det amerikanske fastland, hvor behovet for negerslaver var meget stort med henblik på dyrkning af to vigtige produkter: tobak og bomuld, som med vældigt udbytte produceredes i Virginia og Carolina. Efterhånden som disse områders produkter steg i pris, steg Englands interesse $\mathrm{i}$ også at udnytte områderne syd for Carolina, området fra Savannah-floden og ned mod Florida.

Spanierne havde på et tidligt tidspunkt sat sig fast i Florida, men grænsen mellem dette og Carolina lå ikke fast - det var et så godt som ubetrådt land af europæere, beboet af en rakke store og små indianerstammer. England viste allerede tidligt interesse for området. Charles I bortskænkede det således rundhåndet til en af sine embedsmand i I63orne under betegnelsen Carolina Florida, men det blev det ikke mere koloniscret af. Forholdet mellem England og Spanien var i de forste årtier af $\mathrm{I}$ 700-tallet meget dårligt, navnlig fordi England havde sat sig fast på Spaniens vigtigste punkt: Gibraltar, men også fordi briterne drev smughandel på spanske kolonier. Walpole, Englands store minister under George I, ønskede helst fred og overvejede derfor alvorligt at foreslå et bytte, hvorefter Spanien fik Gibraltar tilbage mod at overlade Florida til England. Det lykkedes som bekendt ikke, men englænderne disponerede fortsat over området syd for Savannah. I I 177 fik Sir Robert Mountgomery (nu oftest stavet Montgomery) overladt området til kolonisering. Han udkastede en fantastisk plan, kaldte "sit rige" the markgravate of Azilia og offentliggjorde en pragtfuld bebyggelsesplan skabt over barokkens meget avancerede tanker om byplan og forsvarsvarker. Sir Roberts Azilia forblev dog et Utopia - det, som han skildrede som 
„the future Eden", forblev netop så vildt og ubeboct som Eden - i hvert fald af hvide mennesker. ${ }^{2}$ )

I lobet af I 720 rne blev det engelsk-spanske forhold stadig forvarret. De hovedrige plantageejere i Carolina blev bekymrede for militære overfald, navnlig efter at Spanien og Frankrig, der ejede Mississippidalen, sluttede sig sammen i falles irritation over engelsk politik bl.a. i Amerika. De to modstandere sluttede forbund med to store grupper af indianere, der boede syd for Carolina, Cherokee- og Creek-stammerne, som derefter foretog indfald på plantagerne. Ejerne af disse, the lord proprietors, der tilsammen udgjorde Carolina's styre, sendte jamrende nodråb til London om hjælp til at beskytte deres sydgranse. ${ }^{3}$ ) Denne hjælp var allerede undervejs.

I London sad nemlig på samme tid en meget aktiv, meget begavet og indflydelsesrig mand og tænkte på at oprette en stat neden for SydCarolina, det kommende Georgia. Det var general James Edward Oglethorpe, født 1689 , der, efter at have deltaget $\mathrm{i}$ de mange års krige på Kontinentet, nu sad som et højt estimeret medlem af Underhuset. Skønt adelig og særdeles velhavende var Oglethorpe stærkt optaget af socialc sporgsmål. Som medlem af en parlamentskommission vedrorende galdsfangslerne havde han fået stærk medfolelse med de tusinder af ulykkelige mennesker, der mere eller mindre uforskyldt var blevet "pensionærer" i gældsfangslerne. Det var jo ikke længe siden, at England var blevet rystet af den store skandale med spekulationen omkring "The South Sea Company" I720-21, der havde ruineret store mangder af spekulanter. Oglethorpe fik nu den idé, at han ville oprette en stat i Amerika og dertil bringe Londons uforskyldt fattige, give dem et stykke jord og så gentage den succes, som de forrige generationer havde oplevet i Virginia og Carolina. Oprindelig udgik ideen vistnok fra en kreds af filantropiske rigmand samlet omkring presten Thomas Bray, der grundlagde The Society for the Propagalion of Christian Knowledge. Det lykkedes ham at overbevise de andre medlemmer af fængselskommissionen om planens muligheder. Der dannede sig da en gruppe af indflydelsesrige parlamentsmedlemmer, der ansogte Parlamentet og kong George II om oprettelse af et charter med henblik på dannelsen af staten Georgia. ${ }^{4}$ ) Efter en hel del forviklinger lykkedes dette i 1732 . I de forste $2 \mathrm{I}$ år skulle ledelsen ligge $\mathrm{i}$ hænderne på den nævnte gruppe, der organiseredes som en styrelse af trustees med et forretningsudvalg, hvor Oglethorpe og Sir John Percival, senere earl of Egmont, var de ledende. ${ }^{5}$ ) Med et enestående forretningstalent lykkedes det de to at indsamle mere end $£$ I00.000 og at få en kolossal publicity omkring projektet. I november 
samme år rejste Oglethorpe personligt sammen med 88 vardige fattige af sted som Georgias forste indbyggere. De skabte grundlaget for den kommende stat ved at rejse byen Savannah ved flodens udløb, bygget som et militært anlæg efter en geometrisk plan, som byen endnu den dag i dag har bevaret. Oglethorpes fortid som officer fornagtede sig ikke det hele havde et meget militært præg. Men også som diplomat havde han evner - han skabte således en udsoning med de omkringboende indianere og medbragte ved sin hjemrejse indianerhøvdingen Tomochichi $o g$ hans familie til London, hvor de blev fejret og fremvist ved hoffet og blandt adelen.

Den koloni, som general Oglethorpe pustede liv i, Georgia, skulle være et udtryk for oplysningstidens bedste ideer. På to vigtige områder udtrykte den tidens smukkeste humanitære tanker, et forvarsel om senere tider. For det forste fik han trods modstand gennemfort forbud mod indforsel af negerslaver til den nye stat. Dette var selvfolgelig nok et udtryk for menneskelig medfølelse - men også fordi kolonien jo havde en militar mission som stødpudestat for Carolina. Negere i Georgia kunne i tilfælde af krig falde englænderne i ryggen, eventuelt i samarbejde med indianerne. Oglethorpe henviste $\mathrm{i}$ så henseende til dårlige erfaringer $\mathrm{i}$ de ikke så fjerne danske kolonier, nemlig den blodige negeropstand på St. Jan I $\left.733 \cdot{ }^{6}\right)$ Rygtet om denne skabte betænkeligheder også på det amerikanske fastland. Det varede ganske vist ikke længe, forend Georgias farmere opdagede, at uden negrenes arbejdskraft ville det store okonomiske boom, de ventede, udeblive, så forbudet lod sig kun opretholde et par år. - Lige så smuk var Oglethorpes idé om et generelt forbud mod indforsel af rom, en liflig drik der skabte store problemer i hele området og ikke mindst bidrog til nedbrydelse af indianernes sclvopholdelsesdrift. Også dette var dog svart at opretholde - Savannahfloden var ikke bred nok til at forhindre Georgias indbyggere $\mathbf{i}$ at tage på indkøbsture ind i nabostaten, der vrimlede med sukkerror og destillerier.

Fra spiren til staten Georgia, hvorfra USA's præsident blev hentet 245 år senere, og fra det myldrende liv i London City må vi nu vende os til midten af Europa, hvor der også skete sære ting i i 73orne. Trods mere end et århundrede med voldsomme opgør i Reformationens kølvand var der endnu i begyndelsen af I 7oo-tallet uro på det religiøse område i Tyskland. Katolikkerne fortsatte forsøget på en modreformation, og blandt lutheranerne opstod mange steder nye vakkelser med forsøg på en inderliggorelse og fornyelse af de lutherske dogmer, således pietismen. Særlig starke var modsætningerne i ærkebiskopdømmet Salz- 
burg, hvor Luthers lære havde fået fodfæeste $\mathrm{i}$ en væsentlig del af den menige befolkning. Langt tilbage i i6oo-tallet havde de katolske magthavere chikaneret protestanterne, men kun med det resultat at disses tro blev inderligere og mere stædig. Konflikten endte brat i november I 73 I, da en nytiltrådt ærkebiskop, Leopold Anton greve af Firmian, ved et s.k. emigrationspatent udviste samtlige lutheranere fra sit rige med en måneds varsel. Det drejede sig om ialt 30.000 mennesker, næsten $10 \%$ af alle hans undersåtter, der hjemløse strømmede nordpå mod de lutheranske lande for at finde asyl. ${ }^{7}$ ) Sagen vakte umådelig opsigt over hele Europa; i Tyskland blev disse lutheranismens martyrer modtaget med åbne arme, og der foranstaltedes indsamlinger også langt uden for Tysklands grænser. General Oglethorpe rejste således sagen i Underhuset og foranledigede, at den engelske konge opfordrede alle sine protestantiske kolleger i Europa til en indsamling til de salzburgske stakler. Denne opfordring blev naturligvis fulgt af den pietistiske dansk-norske konge, Christian VI. Ved kollekt i samtlige dobbeltmonarkiets kirker indsamledes den betydelige sum af over $7.000 \mathrm{rdl}$, i april $1732 .{ }^{8}$ ) Nu skete der tilsyneladende bare det beklagelige, at pengene aldrig kom de nodlidende salzburgere til gode - i i 79I blev det opdaget, at belobet stadig henstod på en konto i Rentekammeret, og at forstesekretæren i Kirkeinspektionskollegict i 50 år havde hævet renterne af de 7000 rdl. som supplement til sin lon!! Nu blev kirkegængernes skillinger inddraget af Danske Kancelli og forsvandt i statskassen..$^{9}$ ) - Der hersker dog lidt mystik om sagen: af et brev fra Augsburg fra februar i 733 fremgår det, at et beløb på 4.000 rdl. var på vej fra Danmark til pastor Francke i Halle som hjælp til salzburgerne - måske var det Christian VI's personlige gave, der var på vej - måske var de ikke på vej alligevel?! ${ }^{10}$ )

Storstedelen af de mange tusinde salzburgere blev modtaget af den preussiske konge. I den nordlige del af hans rige, Lithauen, havde pesten raset og udslettet en stor del af befolkningen, og nu bod han salzburgerne velkommen og uddelte gavmildt af det forladte bondergods. Men der var også andre lande, der gerne ville modtage nogle af dem. I London fik man oje på disse strabsomme emigranter - her var gode, solide kolonister - de kunne bruges i Georgia!

Af ukendte grunde var the trustees of Georgia blevet forhindret $i$ fortsat at tage deres kolonister blandt Englands fattige befolkning, nu skulle de hentes fra Kontinentet. Dette skete ved hjælp af det førnævite veldxdige selskab, The Society for the Propagation of Christian Knowledge, der forenede det himmelske med det jordiske - bestyrelsen bestod af omtrent de samme herrer som the trustees of Georgia. Ad to veje fik man 
forbindelse med salzburgerne: dels gennem den fromme pietistiske præst i Augsburg, Samuel Urlsberger, der tidligere havde været præst ved den tyske kirke i London, dels gennem Englands eller rettere det engelskejede Hannovers representant ved rigsdagen i Regensburg, Johann von Reck. Der blev da sat en omfattende propaganda i gang blandt salzburgerne, som fortalte om de herlige udsigter for dem, der meldte sig til den næste ekspedition til Georgia. De blev lovet fri rejse, et stykke jord i det nye land, gratis forsyning med varktøj og mad i det første år samt skattefrihed de forste ti år. Til at organisere og lede salzburgernes rejse til Georgia leverede den hannoveranske gesandt i Regensburg manden - det blev hans brorson, den da kun 22-årige Philipp Georg Friederich von Reck.

Hermed er vi nået frem til vort udgangspunkt. Det arkiv, der nu findes i Kgl. Bibl.s håndskriftsamling, hidrører nemlig fra Philipp Georg Friederich von Reck. Denne unge mand hørte til en patricierslagt fra egnen omkring Goslar i Harzen. Hans far var amtmand i Windhausen, og selv synes han tidligt at have varet i forbindelse med pietismen, sådan som den udgik fra universitetet i Halle - den bevægelse, der også rørte sig blandt de salzburgske flygtninge og deres åndelige forer pastor Urlsberger i Augsburg. Hvordan von Reck har set ud, ved vi kun lidt om; men man får et ganske godt indtryk af den 22-årige af folgende passus i et brev fra én af the trustees, kaptajn Corram, der traf ham i England:

„... Mr. De Reck is a Clever Young Gentleman very much like Mr. Ogelthorpe tho not altogether so thin in his face. Yet as handsome to the full, he looks as much a nobleman as any I have seen, and his behaviour is very engaging being of an Excellent good Humour of good understanding and Prudence. I fancy you had a wrong notion of him, the Ministers and Mr. Butjenter pay him great difference, his Garb, his Person and his Equipage (which is likely man servant (Mr. Schweikert) in a happy levery) seems to belong to him, in short I can see no fault in him Yet".

Corram fandt heller ingen fejl senere, for et par uger efter tilføjer han, at jo mere han lærte ham at kende, des bedre kunne han lide ham. ${ }^{11}$ ) At en senere uven og konkurrent til ham kaldte ham overfladisk og indbildsk (flüchtig und eitel) kan måske afrunde billedet skønt skrevet midt i en konflikt. ${ }^{12}$ ) Mange vidnesbyrd viser $\mathbf{i}$ hvert fald, at vi her har at gore med en energisk og temperamentsfuld ung mand.

Vi træffer von Reck forste gang i Augsburg, da han i oktober 1733 præesenterede sig som rejseforer for de 44 første salzburgere, som pastor 
Urlsberger havde samlet. I de følgende 3 måneder rejste gruppen langsomt op gennem Tyskland, sejlede ad floden Main og siden på Rhinen op til Rotterdam. I december modtoges von Reck og hans gruppe i Dover af representanter fra the Society for Promoting Christian Knowledge og for the trustees. Efter at være blevet udstyret på alle måder sejlede gruppen af sted med skibet Purisburg med kurs mod Georgia. Denne rejse kom til at tage 2 måneder - ikke usædvanligt dengang for den tur over Atlanten, der nu tager 7 timer. Alle ombord gennemgik frygtelige kvaler, men nåede dog frem i slutningen af marts 1734 . Medens salzburgerne kom sig i Savannah, red von Reck og general Oglethorpe ind $\mathrm{i}$ landet for at finde et passende landskab til de nye indbyggere. Von Reck valgte et skovklædt sted mellem to bifloder til Savannahfloden, ca. $30 \mathrm{~km}$ nord for byen af samme navn. Salzburgerne kaldte kolonien for Ebenezer, da de snart efter kom til stedet, og nu begyndte det hårde liv. Som virkelige nybyggere måtte de rydde skoven, rejse huse og forsoge at fă en afgrode af jorden. Von Reck sendte en begejstret beskrivelse hjem om stedets frugtbarhed og herlighed. Men hans ojne må have været blændet efter de mange måneder på havet; for det viste sig snart, at jorden var ufrugtbar, klimaet fugtigt og det „krystalklare“ vand ubrugeligt. Hvor meget end salzburgerne, der det folgende år ogedes med et nyt rejseselskab på 52, bad og klagede til Herren i himlen og myndighederne i Savannah, gik det dårligt med dyrkningen, og sygdom bredte sig blandt indbyggerne.

Det opdagede von Reck imidlertid ikke i første omgang, for han vendte temmelig hurtigt tilbage til Europa for at samle et nyt rejseselskab i Augsburg. Det viste sig nu sværere end for at hverve salzburgere, skont pastor Urlsberger havde ladet trykke og udsprede de mest rosenrode rapporter om Georgias herligheder. Men von Reck's energi og tolerance var større end Urlsbergers - for ham var lutheranere et vidt begreb. Han besøgte således Herrnhut i Schlesien, hvor grev Zinsendorf havde skabt den beromte brodremenighed, hvis missionsiver var storre end andre pietisters. I I 73I havde Zinsendorf været i København, og beretningen om Hans Egedes virksomhed på Gronland og om negrenes forhold på St. Thomas gjorde så stærkt indtryk på ham, at han samme år sendte nogle af sine brodre til både de kolde og de varme danske kolonier. $\mathrm{Nu}$ ville han også missionere i Georgia. En gruppe af hans brødre, de s.k. Schwenkfeldere, blev sendt af sted i I 732; men i England forbrød de sig mod deres åndelige fyrstes vilje ved i stedet at rejse til Pennsylvania og dér grundlægge en koloni. ${ }^{13}$ ) - Von Recks indbydelse til herrnhuterne i I 735 blev modtaget med taknemmelighed. Det viste sig 
imidlertid, at Urlsberger blev fornærmet over von Recks nævenyttighed, og denne modtog derfor en veritabel „næse“ fra London. Oglethorpe var dog på von Recks side og åbnede i sidste ojeblik adgang også for de herrnhutiske brødre. Men von Recks nidkærhed for Georgia var så stor, at hans onkel i Regensburg anbefalede Urlsberger at nedkøle hans iver lidt :

„... I hope you can keep the Religious Fire and Zeal of My Nephew within due bounds, that it may tend only to Honour of God \& the benefit of His Church ". ${ }^{14}$ ) "His Church" var Halle-pietismens og ikke andre lutheraneres, hvor fromme de end var.

Herrnhuternes koloni i Georgia blev ikke nogen succes. De blev ugleset, fordi de ikke ville bære våben ligesom de øvrige kolonister. Herrnhuterne flyttede til Pennsylvanien, deres „biskop“ David Nietschmann, rejste til menigheden på St. Thomas, hvor han fik stor betydning.

Den unge hedspore var nu indstillet på at slå sig ned i Georgia for resten af sit liv. Da han nåcde Dover med det næste rejseselskab, sikrede han sig selv lofte om et godt stort stykke land, 500 acres, i nærheden af Ebenezer - von Reck ville være velhavende plantagebaron ligesom dem nord for Savannahfloden. I oktober I 735 kom han til England med sit rejseselskab og mødte andre, der også ville til Georgia. Tilsammen var der nu så mange, at der måtte to skibe til. På Simmonds residerede Oglethorpe, på London Merchant von Reck. Disse to skibes rejse til Georgia blev spændende i flere henscender. Dels blev turen usædvanlig langstrakt - I I3 dage kom de stakkels rejsende til at tilbringe på skibene - de forste fire uger i den engelske Kanal syd for øen Wight, hvor man ventede på den rigtige vind. Men desuden blev rejsen også af vældig rækkevidde i kirkehistorisk henseende. Ombord på skibene var nemlig foruden salzburgere og herrnhuter også en ung engelsk teolog ved navn John Wesley, der i Cambridge havde gjort sig reformistiske tanker sammen med en lille gruppe studenter. Nu var han, hans broder og en ven på vej til Georgia - de ville missionere blandt de vilde indianere. På skibet traf Wesley de herrnhutiske brødre, og deres nidkære fromhed gjorde et overvaldende indtryk på ham. Under de tre måneders gyngende samvær i nøddeskaller på verdenshavet skabte Wesley rammerne til en ny trosretning, metodismen, der skulle blive en religion med millioner af tilhangere verden over.

Der er bevaret flere dagboger fra den lange rejse, der viser, hvordan Wesley og herrnhuterne fandt hinanden. ${ }^{15}$ ) Under de talrige voldsomme storme, der fik skibene til at ryste og rulle så forferdende, oplevede alle de små våde mennesker ombord den rene dødsangst - ikke mærkeligt da, 
at dette var stedet til at gøre op med deres barnetro og søge religionens trøst.

Men bonnerne, salmesangen og bibellæsningen var ikke forgæves. Den 5. februar 1736 betrådte kolonisterne Georgias jord. General Oglethorpe begyndte straks at regere sit rige. Han beordrede således forst salzburgerne sydpå til fortet Friderica på den sandede ø St. Simon ca. $100 \mathrm{~km}$ syd for Savannah, hvor de skulle tjene som forpost mod spanske angreb, Men det nægtede de ellers så medgørlige salzburgere, der elskede og beundrede generalen. De ville forenes med deres brødre i Ebenezer, og von Reck rejste dertil i forvejen med kano op ad floden. Han fandt kolonien $\mathrm{i}$ en sørgelig forfatning både åndeligt og materielt. Malaria og dysenteri hærgede, korn og kvæg ville ikke rigtig trives på det fugtige område, og ulve åd fjerkræet. Desuden var der opstået strid i kolonien. Den mand, der havde fort gruppe nr. 2 til Ebenezer, Johann Vat, var kommet $\mathrm{i}$ konflikt med de to pietistiske præster på stedet, og striden var endt med, at Vat havde låset forrådshuset grundigt af og var rejst fra kolonien i vrede medførende nøglen til alle levnedsmidlerne. Det lykkedes imidlertid von Reck at skabe fred på stedet - Vat blev afskediget og forrådskamrene åbnet på ny. Værre var det med den genstridige natur. Salzburgerne havde allerede i i 734 spurgt the trustecs i London, om de ikke måtte flytte til et bedre sted, men fået nej. Nu tog imidlertid vor kxkke unge helt sagen i sin egen hånd og udså et nyt sted nogle kilometer derfra ved selve Savannah-floden, et "Neu-Ebenezer", der blev udlagt efter nyeste geometriske systemer og blev en blomstrende og stadig voksende koloni i de folgende årtier. ${ }^{16}$ )

Med forenede kræfter begyndte salzburgerne nu forfra med at bryde skoven og gore jorden tjenlig til afgrøde. Von Reck synes at have varet en fortrinlig organisator, men han kom ikke som planlagt til at leve resten af sine dage i Ebenezer. Han og hans yngre bror, Ernst Ludwig, fik begge "tredages-feber" - formentlig malaria - ligesom de fleste andre af salzburgerne. Von Reck var bange for sit liv, han lagde sig syg i Savannah, lod sig pleje i månedsvis af John Wesley og foretog siden en rekreationstur til New York og Pennsylvania. I begyndelsen af ${ }_{1} 73^{8}$ rejste han tilbage til Europa medbringende bl.a. en bog fuld af tegninger og akvareller.

Der er bevaret en usædvanlig mængde skriftlige kilder til belysning af Georgias tidligste kolonisering. Foruden et omfattende arkiv efter de engelske grundlæggere, the trustees i London, med deres korrespondance tværs over Atlanten, en række meget detaljerede dagboger fra de im- 
plicerede. Ikke mindre detaljerede er de beretninger, som salzburgernes åndelige fader, pastor Urlsberger modtog $\mathrm{i}$ Augsburg $\mathrm{i}$ form af breve fra de to præster i Ebenezer, Boltzius og Gronau. Urlsberger udgav i de følgende år disse beretninger under betegnelsen „Ausführliche Nachrichten von der Königlich-gross-brittanischen Colonie Salzburgischer Emigranten in America “, 3 bind, Halle I 735-52. Det var dog en stærkt sminket og censureret udgave, der skulle tjene til at kalde flere til Amerika - dagligdags oplevelser indhyllet i en uhyre mængde gudelige betragtninger og bibelcitater. ${ }^{17}$ )

Men i dette usadvanligt store kildemateriale, hvor man kan folge kolonisterne næsten dag for dag, savner man netop et indtryk af, hvordan det hele egentlig så ud den gang $\mathrm{i}$ det næsten jomfruclige, halvtropiske område - hvad så disse mennesker, der havde travlt med at få fodfæste i Georgia og kæmpede med liv og død? Hvad der hidtil foreligger af billedmateriale er såre fattigt - nogle få kobberstik fremstillet senere i Augsburg og London med henblik på at skaffe Georgia nye indbyggere. For områdets fugle og planter er man bedre hjulpet, idet en engelsk naturforsker Mark Catesby i 1720 orne gennemrejste området og siden i I 73I, I754 og I77 I udgav en rakke kunstfardige plancher derfra. ${ }^{18}$ )

Von Recks tegninger i Ny kgl. Samling $5654^{\circ} \mathrm{er}$ ikke kunstfardige og stilprægede som I 7oo-tallets kobberstik. De er tydeligvis fremstillet af én, der nok har haft professionelt håndelag til at tegne præcist og smukt, men ikke for kunstens skyld - derimod med henblik på et objektivt udtryk på samme måde som etnografer nu om dage bruger fotografiet som dokumentation til deres fremstilling. Arkivet består af fire dele: 1) en skitsebog i et smukt præget læderbind $(36,5 \times 28,8 \mathrm{~cm})$, hvori 44 tegninger og akvareller, 2) tolv lose tegninger, hvoraf nogle i meget stort format. 3) manuskriptet til en beretning om Georgia, som von Reck mange år senere (1777) udgav i Hamburg og 4) en rakke breve og papirer vedrørende von Recks rejse til Georgia 1736 , heriblandt et originalt brev på latin fra general Oglethorpe til grev Zinsendorf i Herrnhut fra februar ${ }^{1} 735^{19}$ ) samt en regning på von Recks indkøb af værktøj inden afrejsen i 1735 . Af disse grupper er tegningerne naturligvis langt de interessanteste som historisk dokumentation. Samtidig rejser de også en række vanskelige kildekritiske problemer, som i det folgende skal nærmere belyses.

Det forste sporgsmål, der rejser sig er: hvem har tegnet de $5^{6}$ tegninger? Desværre lader dette sig ikke besvare med sikkerhed. Vist er det i hvert fald, at ejeren af skitsebogen ved forskellige lejligheder har udlånt den til andre, der ikke nær havde de samme fardigheder $\mathrm{i}$ at tegne. 


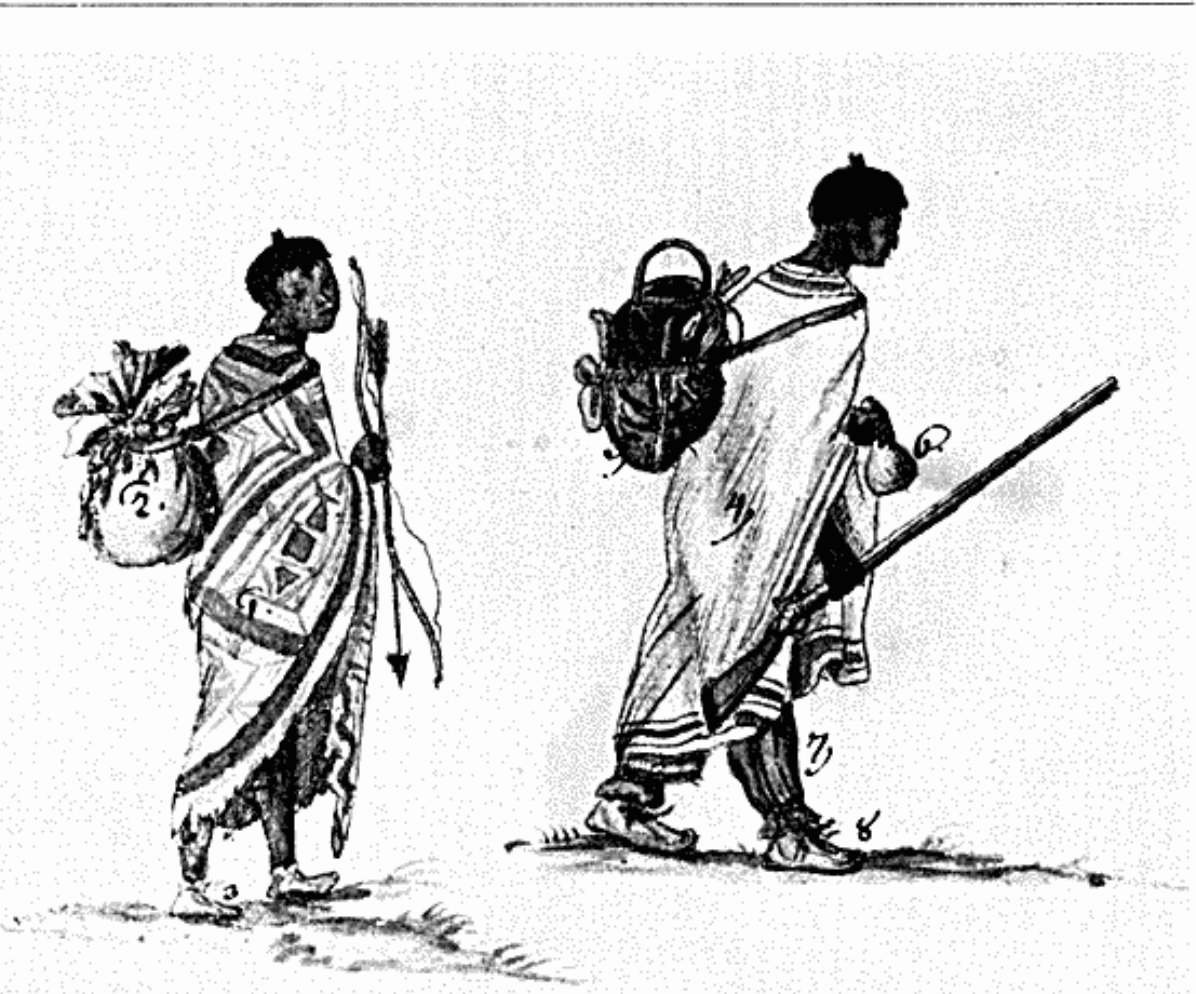

„Indianere, der går på jagt “. Den lille top på hovedet viser, at det er uchi-indianere (se s. 84). Under jagten levede de i ugevis som nomader medbringende kokkenudstyr og mad i rygsakke. Indianeren til venstre barer som tappe et dyreskind bemalet med rode og okker farver. Den anden indianer viser den forste europaiske påvirkning. Hans kappe er en engelsk plaid, der kunne købes i Charleston for to rảdyrskind. For ca. fem skind havde han kobt skydevåbnet. Denne handel mellem indianere og nybyggere betod, at der fra Charleston kunne eksporteres mere end roo.ooo skind til England pr. år. Lidt formindsket udsnit. Ny kgl. Saml. $5654^{\circ}$.

Fem tegninger i bogen er udfort af en langt mere naiv person, og blandt de øvrige halvt hundrede tegninger er der også nogle, der ikke ligner den stil, der præger hoveddelen. Hvem der har lavet disse såvel som de meget naive skitser, er man helt uden midler til at afgore. Skitsebogen indeholder intet sted noget ejermærke eller signaturer, og der er intet i de ellers uhyre udforlige beretninger der antyder, at en tegner har været på færde.

De meget udførlige tekster til billederne, hvorom nedenfor, lader det i hvert fald uden for al tvivl, at tegningerne hidrorer fra den tredie transport af salzburgere, den der afrejste fra England i oktober 1735 med von Reck. Mest nærliggende er det naturligvis at tillægge von Reck selv 
æren af at være kunstneren. Selve den omstændighed, at tegningerne er fundet $\mathrm{i}$ von Recks efterladenskaber, er dog ikke i sig selv noget bevis herfor - han kan udmærket have erhvervet tegningerne fra en af de andre i kolonien - ikke så få af salzburgerne døde i disse år af febersygdomme, og skitsebogen kan være efterladt af en af disse. Når kilderne som ovenfor skildret giver et indtryk af von Reck som en meget ungdommelig og meget rastløs mand, der ikke viser tegn på den tålmodighed, der skal til for at udføre de fint udførte og detailrige akvareller, har man de indicier, der peger vak fra Philipp von Reck selv. Pa den anden side er der andre træk, der meget overbevisende peger på von Reck som kunstneren. Der er ingen tvivl om, at den unge mand var særdeles interesseret i naturhistorie og antropologi. Det fremgår til fulde af de rapporter, som von Reck hjemsendte til the trustees i London og til Urlsberger i Augsburg. Heri gennemgår han områdets plante- og dyreverden og beskaftiger sig en del med de nærboende indianerstammer. Afgørende med hensyn til identifikation af tegningernes ophavsmand er von Recks rapport vedrørende rejsen $\mathbf{I} 735-36{ }^{20}$ ) Gennemgår man denne dagbog fra det forste halve års ophold i Ebenezer med tegningerne, vil man nemlig finde, at der er en tydelig overensstemmelse mellem det, der skildres i dagbogen, og det, billederne forestiller. Desuden er der dele af teksten til tegningerne, der går igen i dagbogen, omtale af forhold, der ikke kan findes i andre skildringer fra tiden. Det er da nærliggende at slutte, at tegningerne er fremstillet med henblik på at illustrere den fremstilling, han skulle hjemsende, og som han vidste ville blive trykt i Augsburg i Urlsbergers „Ausführliche Nachrichten ...“. Sammenhængen mellem dagbogen og tegningerne har fundet en slags bekræftelse, efter at et utrykt brev er dukket op i Franckesche Stiftung i Halle, hvortil Urlsbergers arkiv siden kom. Reck skriver her, netop hjemvendt fra Georgia i I 738 : „... Es würde viel zu weitläufig fallen, von allen eine ausführliche Nachricht schriftlich zu geben, welches ich solange verschiebe, bis ich nach Gottes Willen die Ehre habe Ew: Hochwürden meine Diaria und Zeichnungen Selbsten zu überrreichen “. ${ }^{21}$ )

Det synes da helt nærliggende at slutte, at von Reck selv er ophavsmand til hoveddelen af akvarellerne, og det så meget mere, som hånd-

Pä modstáende side: En side af von Recks skitsebog. Øverst en koralslange, som han kalder „Eine junge Wasserschlange“. Derunder to snegle, en sort hasselnød og to forskellige typer nødder eller agern. Nederst en alligator, hvoraf mange levede i Savannah-floden. Teksten nederst fortæller, at de om vinteren spiser nogle få af de afbildede nødder og lever kun af dem, medens de ligger i dvale. Formindsket. Akvarel i Ny kgl. Saml. $5654^{\circ}$. 


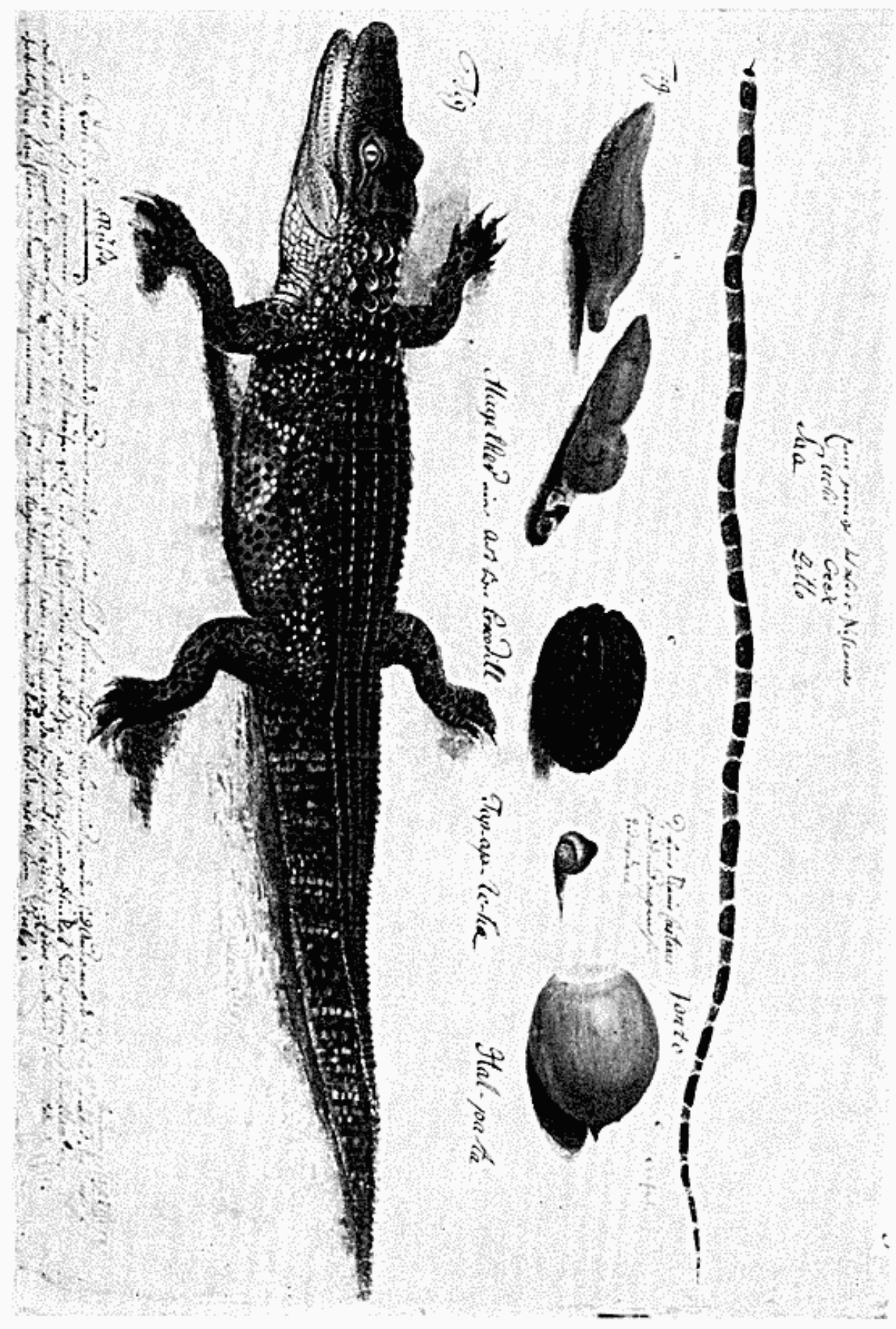


skriften i teksterne med ret stor sikkerhed kan identificeres som von Recks egen skrift. Foran et par af tegningerne står: „Dieses ist nicht völlig ausgemahlet" - man kan tænke sig, at han er blevet afbrudt, da han malede billedet og i teksten minder sig selv om senere at gøre det færdigt. Den sidste tvivl om Philipp von Reck som kunstneren kunne bestå deri, at billederne var fremstillet af hans fem år yngre bror Ernst Ludwig, som fulgte broderen på den anden rejse til Georgia. Det er ikke utænkeligt, at Philipp von Reck tog broderen med netop for at tilvejebringe det dokumentariske materiale, der senere kunne udnyttes i Europa - selv havde han jo nok at gore med at kommandere med sine rejseselskaber. ${ }^{22}$ ) Der er dog ingen mulighed for at underbygge dette nærmere - og det er nok mest rimeligt at antage, at skitsebogen og tegningerne deri er Philipp von Recks egne. Han synes på et tidspunkt at have arbejdet på en udgivelse af dem, for på en stor del af tegningerne (mærkværdigvis også på nogle af de mest naive) er efter de tyske tekster tilføjet forkortelsen „Fig.“, formentlig med tanke på senere tilføjelse af et tal, sådan at tegningerne kunne komme i en rekkefolge svarende til teksten. Formodentlig har det så vist sig for kostbart at gengive dem, og de er da endt i bunden af Philipp von Recks skuffer.

Reproduktion af tegningerne ville have varet vanskeliggjort ved, at von Reck fyldte papiret rundt om dem med sine udførlige, håndskrevne kommentarer. De vidner om hans evne til at skaffe sig oplysninger og om hans gode uddannelse og sprogkundskab. Men det, der også gor kommentarerne interessante er, at von Reck har tilføjet betegnelserne for, hvad billederne forestillede, på to indianske sprog, creek og uchi. Grupper af disse to indianerstammer boede lige i nærheden af Ebenezer $i$ fredelig sameksistens med salzburgerne. Creek-indianerne var en meget stor stamme spredt over betydelige dele af det sydøstlige Amerika. Uchiindianerne derimod var en meget lille gruppe, der synes at have varet i nogen grad undertrykt af creek-indianerne. ${ }^{23}$ ) De talte to helt forskellige sprog - the creeks foragtede og lo af uchierne på grund af deres mærkelige sprog - de brugte nemlig stød ligesom i dansk, men meget mere

Pa modstaende side: I sin rapport til London skrev von Reck om en fest han havde oplevet $\mathrm{i}$ uchi-stammen. Her har han skildret den visuclt og knytter sine kommentarer til numre angivet på billedet: 1) Hytte hvor stammen er forsamlet. 2) En indianer kommer løbende for at berette om sine heltegerninger. 3) En indianer fortæller med stor heftighed om sin heltedåd. 4-5) To dansere, der har en busk fjer $\mathrm{i}$ den ene hånd og et klaptræx i den anden. 6) En keddeltromme. 7) Fem sangere, der ogsả slår med klaptræer. 8) Et træ med "Spanish moss". - Disse traer bekladt med lange taver af grågront mos er et karakteristisk trak i Georgias natur endnu i dag. Formindsket. Akvarel i Ny kgl. Saml. $5654^{\circ}$. 


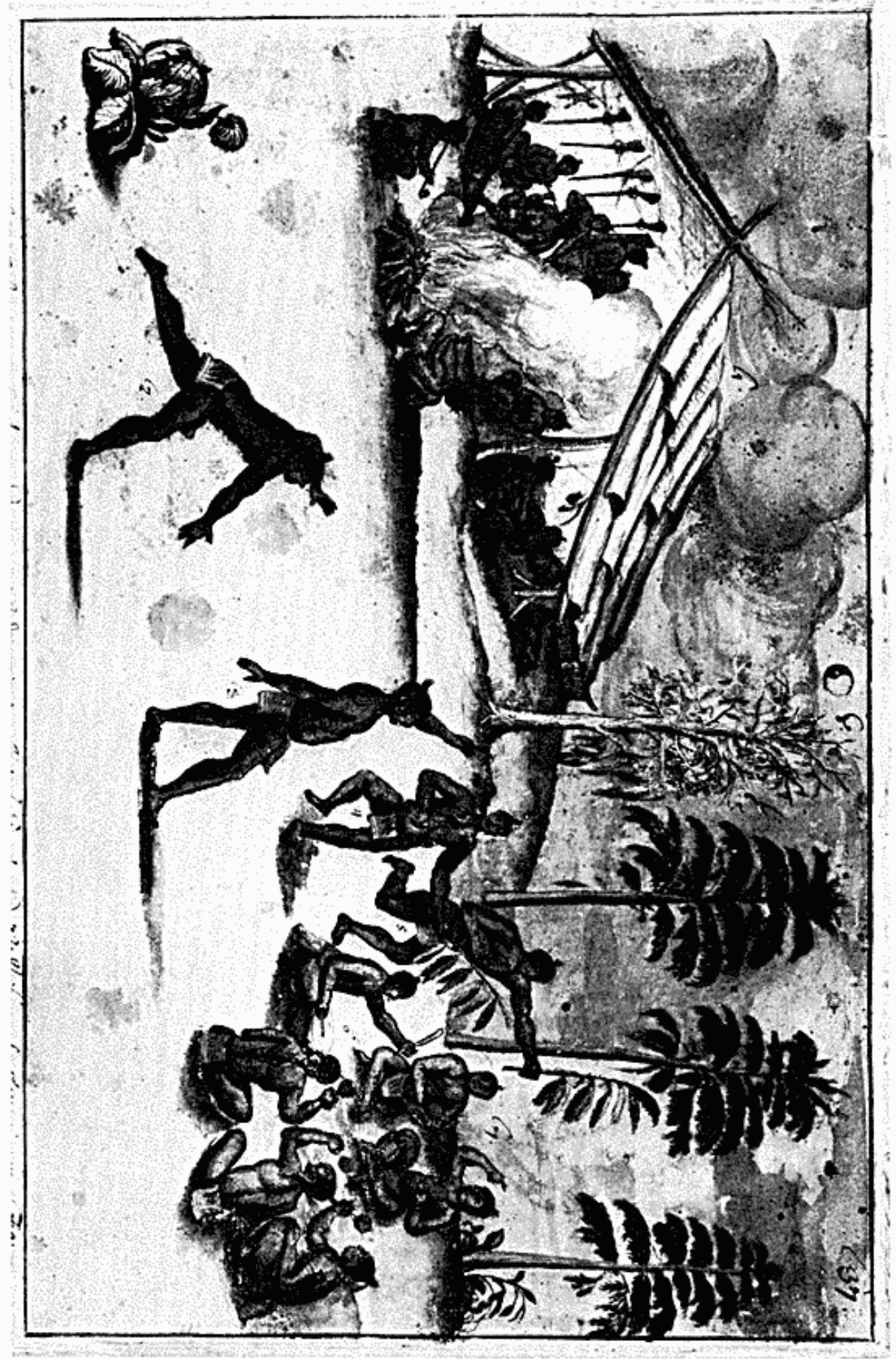


udbredt, således både før og efter enkeltlyde, hvorfor uchiernes tale lød som gøen $\mathrm{i}$ naboernes oren. Indianersprogene er i dag hastigt på vej ud af historien. Af indianere, der taler uchisproget er der i øjeblikket siger og skriver 35 tilbage. Sprogforskere i USA har derfor travlt med at "opfange" disse sprog og nedfalde deres historiske udvikling. For crecksproget er de hidtil tidligste skriftlige optegnelser på sproget fra omkring 1800 , for uchi fra ca. 1830 . Von Recks tegninger er derfor af største interesse for sprogforskere, idet de indianske betegnelser på tegningerne giver bidrag til de to sprog, der er flere generationer aldre end de nu kendte. Salzburgerne havde som næunt stadig omgang med de to stammer, og det var dem om at gore at lære deres sprog, både for at drive handel med dem og for at forsoge at bibringe dem Guds ord. Et af billederne forestiller en gammel indianer, ,welcher sich eine Zeitlang bey mir aufgehalten " - han var nemlig såret $\mathrm{i}$ benet. Det er nærliggende at tænke sig, at denne indianer har kigget von Reck over skulderen, når han tegnede, og sagt på indiansk hvad det forestillede - hvis han var af uchi-stammen, kunne han muligvis også creek-sproget. På en tegning af en anden indianer kan man se, hvordan von Reck har forsøgt at opfange navnet på indianeren fonetisk rigtigt - med blyant har han forsøgt sig med flere varianter af stavningen, inden han med tusch har skrevet: „Scnkaitschi“. Sproghistorisk set er det jo en svaghed, når ordene i komplet ukendte, meget komplicerede sprog skal opfattes og bogstaveres af en europæer. Men han har dog gjort det så godt, at kendere af de to indianersprog kan identificere og oversætte et meget stort antal af ordene på von Recks tegninger.

Von Reck var ret dygtig til både engelsk og fransk. På tegningerne er kommentarerne mest skrevet på tysk, men mange steder også på engelsk og et enkelt sted på meget smukt fransk. ${ }^{24}$ ) Det kniber dog med stavningen af det engelske og navnlig med opfattelsen af ham ukendte ord. Et komisk eksempel findes på en tegning af en såkaldt opossum, det eneste pungdyr på det amerikanske fastland, et dyr på storrelse med en stor hare, kløer og hale som en rotte, men tænder som en hund. Von Reck har fejlagtigt opfattet dette dyr som en vaskebjørn, en racoon, et ord som han staver "a Reckhuhn“, altså hans eget navn med tilføjelse af det tyske ord for høne! Det kunne se ud, som om det var ment som en spøg.

Som i alle kunstneres skitsebøger er rækkefølgen af tegninger helt tilfældig - de er anbragt, hvor der nu var plads. Dog synes bogen at være taget $\mathrm{i}$ brug med tanke på, at tegningerne skulle følge $\mathrm{i}$ samme rækkefølge som oplevelserne, for bogens forste blad rummer en grundplan af skibet London Merchant, som von Reck gik ombord i i Dover i oktober 


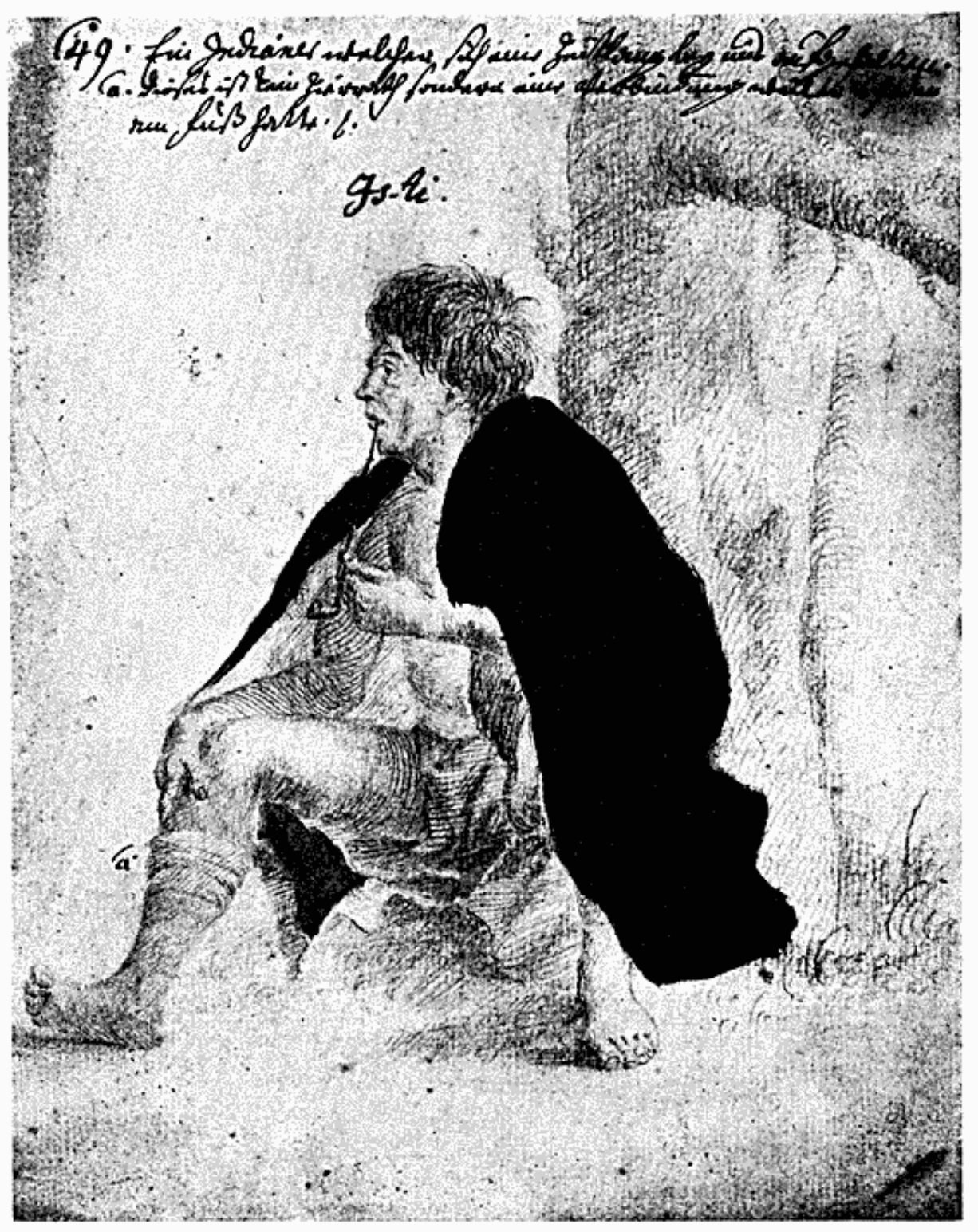

„En indianer, der opholdt sig en tid hos mig“, står der skrevet på tysk over denne tegning. Is-ti betyder ,mand" på creek. Det er sikkert denne indianer, antagelig af uchi-stammen, der har forsynet von Reck med de indianske betegnelser på hans tegninger. Indianeren var såret $\mathrm{i}$ benet. Teksten til a) ved hans hojre ben lyder: „Dette er ikke et smykke, men en forbinding, fordi han havde skadet foden ". Hans kappe er farvet bordeaux-rod. Formindsket. Ny kgl. Saml. $5654^{\circ}$. 
I735, med angivelse af fordelingen af lukaferne til de østrigske og engelske passagerer, den fordeling, som var en vigtig opgave for rejseføreren von Reck. Men derefter er der ingen plan i tegningernes rækkefølge. Fordeler man dem alle efter emne ser man, at det er naturhistorien, der har interesseret von Reck mest: 34 tegninger forestiller træer og planter, 8 viser forskellige fugle, 5 tegninger pattedyr og 2 gengiver fisk. Så er der de historisk set interessante 12 tegninger af de nærboende indianere, og 9 der viser forskellige steder fra rejsen og i Georgia. ${ }^{25}$ )

Når botanikken spiller så stor en rolle blandt tegningerne, afspejler det ikke blot almindelig naturhistorisk interesse hos von Reck, men nok så meget, at det var af afgorende betydning for ham og hans faller i Ebenezer at kende de muligheder, som stedets plantevakst kunne have for opretholdelsen af livet og for en mulig rationel udnyttelse af den med henblik på eksport til Europa. Allerede på et meget tidligt tidspunkt under planlæggelsen af den kommende kolonisation af Georgia gik the trustees i London i gang med en systematisk undersøgelse af, hvilke dyrkningsmuligheder det nye land havde. Endnu for $173^{\circ}$ sendtes en højt uddannet botaniker ud til troperne med henblik på at skaffe nye plantearter til de nye kolonier i Amerika. Dr. William Houstoun fra Skotland rejste i flere år rundt på bl.a. Jamaica og i Mexico og hjemsendte beretninger om mulighederne for at overfore planter til Georgia. Han var oprindelig udsendt af Royal Society, men "overtoges" i I 732 af the trustees of Georgia. I I 733 dode Houstoun imidlertid på Jamaica, og the trustees udsendte derefter hans landsmand og kollega Robert Miller for at fortsætte arbejdet. ${ }^{26}$ ) På et tidspunkt fik Miller så ordre til at overfore sin plantesamling fra Jamaica til Georgia og lade den danne grundlag for en botanisk have uden for byen Savannah. Den systematiske og praktiske måde, hvorpå englænderne greb dette forskningsarbejde an, giver forståelse for, hvordan og hvorfor England måtte blive en verdensmagt. De kommercielle interessenter var dygtige til at koordinere de bestræbelser, der var nødvendige for at skabe et vellykket økonomisk resultat.

Det må ganske vist tilføjes, at dr. Houstouns og Robert Millers bestræbelser vistnok ikke gav store praktiske resultater. Men man stillede i hvert fald store forventninger til nye varesorter, som ikke fandtes i staterne nord for Savannah. Meget tidligt havde man opdaget, at der voksede morbærtræer vildt i Georgia, og man satsede derfor med stor energi på silkeproduktion, hentede silkeorme og eksperter fra Italien. Desuden lagde man vægt på at skaffe farvestoffer til den engelske tekstilindustri. Dr. Houstoun dyrkede således cochenillelus på bestemte planter og 
håbede at kunne få det røde farvestof sat i produktion i Georgia. Det er i samme forbindelse, at von Reck i sine tegninger har beskæftiget sig med indigo-planten, hvoraf man udvinder det blå farvestof, og gengiver et billede af en ,indigofabrik“, „ein Indigotterie“. Det er lykkedes mig at finde hans forlæg for dette, nemlig Pierre Pommet's Histoire Générale des Drogues, der udkom i Paris 1694 (engelsk udgave 1725). En anden vækst, som han har gengivet flere gange, fordi han har ventet sig udbytte af den, er det lille cossini-tra (ilex decidua). Det er en meget småbladet plante, hvis blade indianerne brugte til at brygge te af, en meget velsmagende drik, som von Reck formentlig har tænkt sig at kunne introducere i Europa som et alternativ til den indiske te. Også en slags cacao mente han at have fundet. Han kaldte vaksten satapi; dens latinske navn er assimina, i Amerika kaldes den nu paw-paw. Nogle af salzburgerne må have kigget på, da den blev tegnet, for von Reck har tilføjet til teksten: „Unser Doct: Herrn Zwifler meinet es seye Ricinus Americanus (amerikansk olie), welches oben und unten purgiret"! Den gode lage kan ikke have varet meget bevandret $\mathrm{i}$ botanikken, for sådan ser ricinus slet ikke ud. - En frugt, der har vakt von Recks begejstring i det varme klima, er naturligvis vandmelonen, som han i et ojebliks tørst har portrætteret $\mathrm{i}$ fuld storrelse og med rigtig saftige gronne og rode farver.

Også de andre attraktive tropiske vækster, som Houstoun og Miller havde arbejdet med som cacao, pebber og cocuspalmer, har von Reck tegnet, men skriver over: „Diese Sachen finden sich nicht in Georgien “ ${ }^{27}$ ) Forlæggene for disse er ikke Pommet's ovennævnte værk fra 1725 , men det synes givet, at de er aftegnet fra et eller andet botanisk vark, - hvilket får stå hen. Men tanken om at opdyrke disse frugter på sine 500 acres uden for Ebenezer må have kildret hans fantasi.

Blandt dyretegningerne hersker der en hel del mystik omkring en meget skitsemassig, men drevent tegnet love. Der findes ingen lover i Georgia, og tegningen er da tegnet efter fantasien. Men ovenover står der et indiansk ord: Hutsch-u, der er creekordet for panter, et rovdyr som fandtes i landet. Min eneste forklaring på dette er, at von Reck har forsegt at kommunikere med en af indianerne i nabolaget og herunder har tegnet omridsene af en løve, indtil indianeren har set genkendende ud og udtalt det nærmeste ord for det, han så. Iøvrigt siges det, at indianerne godt kendte en løve, dyrenes konge, som et begreb uden at have set en.

Fra et antropologisk synspunkt er tegningerne af indianere vel nok højdepunkterne i von Recks værk. Som før nævnt boede der to helt forskellige indianerstammer umiddelbart nord for salzburger-kolonien, 
uchi- og creck-indianerne. Helt fra begyndelsen kom de til kolonien, undertiden med hjorte, de havde fanget, meget velkommen mad og skind til de forkomne kolonister. Somme tider kom de også og lavede ravage $\mathrm{i}$ lejren, stærkt beruset af rom, som de havde hentet hinsides Savannah-floden. Von Reck var tydeligvis fascineret af de fantastisk udseende vilde. I sin beretning til London har han fortræffeligt skildret deres beklædning og levevis, og tegningerne er levende illustrationer til denne beskrivelse. ${ }^{28}$ ) Det, som har begejstret amerikanske indianereksperter, der har set akvarellerne, er, at figurerne er så udpræget sete tegneren har ikke hverken besmykket eller karikeret, hvad han så. Hvad der iøvrigt findes af indianerafbildninger fra tiden er preget af tidens stil i Europa, trangen til det kunstlede, forsirede, der prager barokkens skildringer af det eksotiske og som i høj grad forstyrrer det objektive billede. Der fremkom jo ikke så få fantasiskildringer af de oversøiske landes vilde mennesker i i 7oo-tallets litteratur. Illustrationerne blev vel ofte tilvejebragt ved, at de opdagelsesrejsende hjembragte deres skitsebøger på samme måde som von Reck. Disse blev videregivet til datidens illustratorer, kobberstikkerne, der lagde dette slør af sirlig kunstferdighed hen over originalerne. Forlaggene blev ofte odelagt, enten fordi kobberstikkerne indledningsvis stak omridset af billedet direkte gennem skitsens papir ned på pladen; eller også blev skitsen ,væk", fordi kobberstikkeren ikke var alt for interesseret $i$ at vise, hvor meget han havde andret forlægget. Af von Recks indianertegninger er de i I tydeligvis tegnet efter model - for at imponere europxerne dukkede rodhuderne op i vildeste krigsmaling. Men én af tegningerne vekker beskuerens mistanke. I modsatning til de ovrige er figuren gengivet i en lidt unaturlig positur, og så bærer han en bue af den slags, som gud Amor bærer, kunstfærdig, men, som det synes, ubrugelig for en mand, der lever som jæger. Man kunne fristes til at tro, at der her var tale om en kopi fra en bog eller et maleri. Det er et problem, som jeg fortsat arbejder med.

Fra et historisk synspunkt er tegningernes interessanteste del de fire skitser, der viser salzburgernes koloni Neu-Ebenezer under arbejdet med at etablere de første huse og hytter. Her får man et realistisk indtryk af, hvordan alt det, som andre brugte så mange ord på at skildre, virkelig så ud. Det militære præg ses af skildvagterne, der i rigtig militært antræk og med gevar over skulderen virker helt paradoksale midt $\mathbf{i}$ det uhyre ensomme vildnis. De høje palisader rundt om den endnu næppe anlagte by havde også et andet formål end det forsvarsmæssige - de skulle holde grisene og hønsene inde! Det kom nemlig til en lille konflikt mellem de menige kolonister og von Reck, der havde taget land på begge sider af 


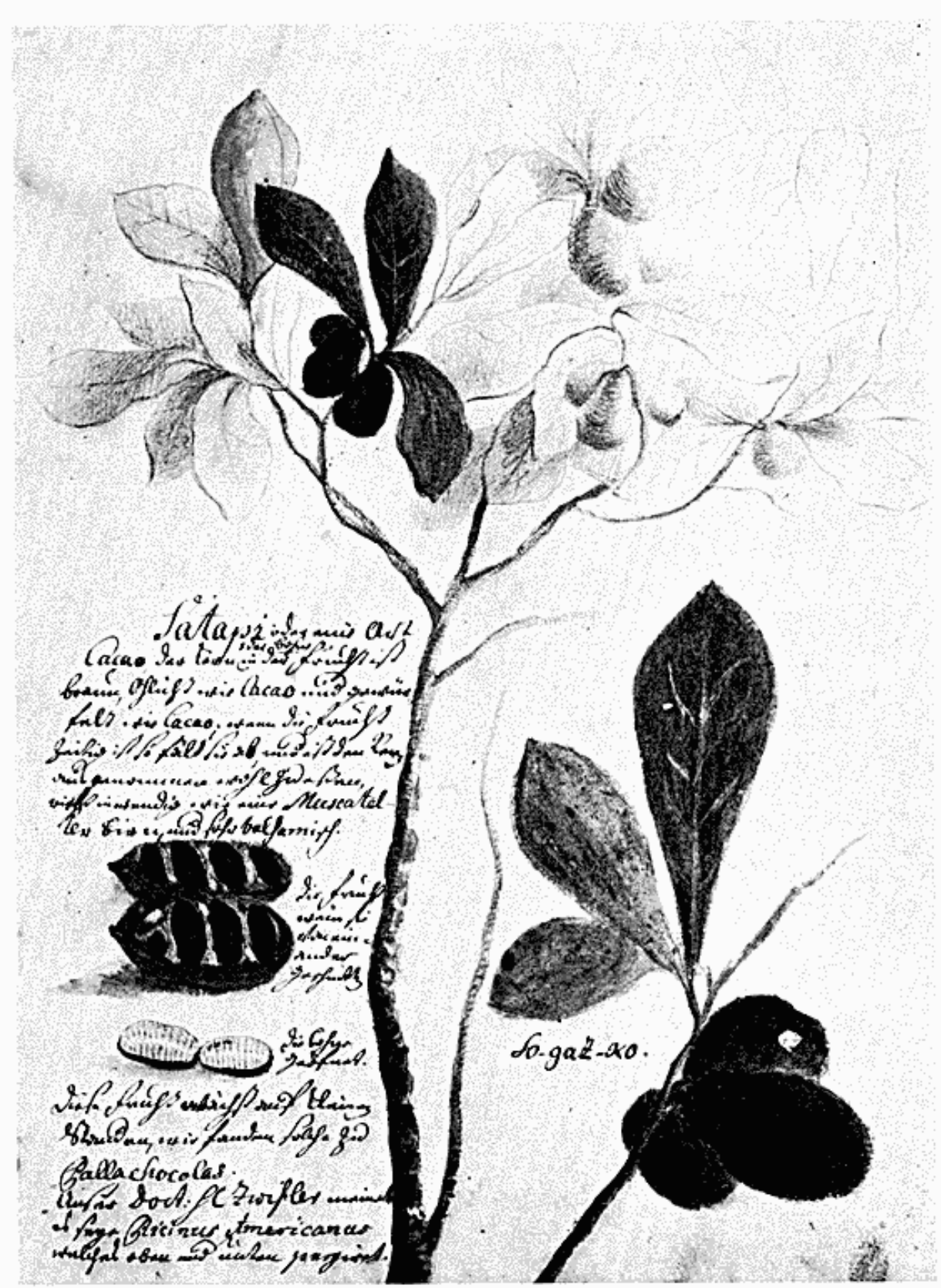

Teksten pâ tegningen lyder: „Satapi oder eine Art Cacao. Der Kern oder Bohne in der Frucht ist braun, oehlicht wie Cacao, wenn dic Frucht zeitig ist so fallt sie ab und ist der Kern ausgenommen wohl zu essen, riecht inwendig wie eine Muscateller Birn und sehr balsamisch. Diese Frucht wächst auf kleinen Standen, wir fanden solche zu Pallachucolas. Unser Doct: Herr Zwifler meinet es seye Ricinus Americanus welches oben und unten purgiret." Det var nu hverken Satapi eller amerikansk olie (ricinus), men pawpaw. Formindsket udsnit. Ny kgl. Saml. $5654^{\circ}$. 
„byen“. Han tolererede ikke, at kolonisternes grise og høns løb ud på hans enemarker, selv om de var aldeles uudnyttede!

Stedet er nu ikke mere bebygget - skoven er vokset hen over Ebenezer. Den blomstrede som koloni $\mathrm{i}$ årene op til den amerikanske revolution; siden blev den forladt, husene forsvandt, tilbage står nu kun en ualmindelig smuk kirkebygning og en stor præstebolig indrettet som museum, begge opforte i i 760 'erne. Men de sidste års stærke vækkelse af amerikanernes etniske bevidsthed har bragt Ebenezer frem i rampelyset igen - en livskraftig menighed har genopvækket et "salzburgsk" selskab omkring kirken, og (hvad værre er) i disse måneder bygges der på stedet for Ebenezer et magtigt konferencecenter $\mathrm{i}$ „colonial style“ inclusive swimmingpools og tennisbaner. Man kan forestille sig, at reproduktioner af von Recks tegninger og akvareller vil blive den foretrukne udsmykning af de nye vagge!

Tilbage står nu spørgsmålet: hvordan endte von Recks arkiv i Kgl. Bibl.? Det hænger sammen med Philipp von Recks videre livsbane, der blev snoet - og lang. Han vendte som næunt tilbage fra Georgia i ${ }_{1} 73^{8}$ sammen med sin bror, endnu ung, 28 år, men hærget af febersygdom og dysenteri. I forste omgang bosatte han sig i det, der var hans religiøse hjemsted, Halle. Uden egentlig uddannelse som han var, indskrev han sig ved universitetet dér som student i jura. Derefter blev hans løbebane den, som deltes af tusinder af tyske adelige uden arveret til godser i denne epoke - han blev embedsmand ved de talrige småstaters hoffer. Først blev han hofmester for prinsen af Anhalt-Köthen, siden regeringsråd i Sachsen-Weimar-Eisenach, flyttede 1757 til Hessen-Kassel og fik med skattevæsenet at gore, indtil franske tropper under den prøjsiske Syvårskrig forjog ham. Mellem hoffet $\mathrm{i}$ Hessen-Kassel og det danske hof var der snævre familieforbindelser, og det var måske inspirationen til, at han i marts 1763 ansogte Rentekammeret i København om stillingen som amtsforvalter og "Hausvogt“ ved grevskabet Rantzau i Holsten, der siden 1724 var kommet under den danske krone. Han bosatte sig da $\mathrm{i}$ Barmstedt mellem Itzehoe og Altona og fungerede i sin stilling lige til han i I 792, 82 år gammel, fik Rentekammerets velsignelse til at gå på pension. Han døde først $\mathrm{I} 79^{8}$, gammel og mæt af dage. ${ }^{29}$ )

Men hvordan tegningerne dernast er kommet fra Barmstedt i Holsten til Slotsholmen i København, skjuler sig i dunkelhed. Givet er det, at de er indlemmet i biblioteket $\mathrm{i}$ årene mellem $\mathrm{I} 79^{8} \mathrm{og} \mathrm{I}_{223}$, de år, hvor $\mathrm{Ny}$ kgl. Samling blev registreret i et systematisk katalog. Derimod kan intet siges om, hvorvidt de er erhvervet af biblioteket som gave eller købt 
på en auktion. Hovedsagen er, at de er bevaret for eftertiden. Materialet vil nu blive udgivet af undertegnede på forlaget Beehive Press i Savannah. Udgaven, der vil bringe farvegengivelser af de fleste af akvarellerne, ventes at udkomme i sidste halvdel af 1978 .

\section{NO'TER}

(1) „Et Volumen, hvori en Decl Tegninger og andet til den nord-amerikanske Naturhistorie og Geographic, med Samlinger til Beskrivelse over de salzburgske Emigranters Etablissement Ebenezer i Provindsen Georgien“. - (2) Charles C. Jones: History of Georgia I, Boston I883, s. 70-77. - (3) Amos A. Ettinger: James Edw. Oglethorpe. Imperial Idealist, Oxford 1936 , s. 1 $72-76$, samt David H. Corkran: The Creek Frontier $1540^{-1} 7_{3}$, Oklahoma 1967, s. 61-96. Carolina var dannet som selvstendig koloni i ${ }_{1} 670$, fra 1730 delt i en nordlig og sydlig stat. - (4) Verner W. Cranc: The Philantropists and the Genesis of Georgia, i: American Historical Review, 192 I, s. 6369. - (5) Charteret er trykt i W. Keith Kavenagh: Foundations of Colonial America, New York 1973. - (6) Ettinger, op.cit. s. 150. Detailed Reports on the Salzburger Emigrants who settled in America, ed. George F. Jones, III, Georgia 1972, s. 311. Om dette vark se note 17. - (7) Felix F. Strauss: A Brief Survey of Protestantism in Archiepiscopal Salzburg and the Emigration of $\mathrm{I}_{732}$, i: Georgia Historical Quarterly, Savannah, 1933, s. 29-59. - (8) Kirkehistoriske Samlinger, 3. rk. 3. bd., I881, s. 47678. - (9) Ibid., 3. rk., bd. V, s. 76 f. - (10) Henry Newman's Salzburger Letterbooks, ed. George F. Jones, Athens 1966, s. 29I, jfr. s. 400 .

(11) Ibid. s. 396 og 407. - (12) Herman Winde: Die Frühgeschichte der Lutheranischen Kirche in Georgia (utrykt disputats), II, Halle 1960, s. 322, note 1172. (13) Adelaide L. Fries: The Moravians in Georgia, Raleigh, N.C., 1905, s. 35 . (14) Henry Newman's Letterbooks s. 534. - (15) Nogle af dem er gengivet parallelt i Adelaide L. Fries: The Moravians in Georgia, s. IoI-21. Von Recks dagbog er gengivet i Samuel Urlsperger: Ausführliche Nachricht von den Salzburgischen Emigranten, die sich in America niedergelassen haben ... I, Halle 1735-44, s. 803-53. John Wesley's meget udforlige dagbog: The Journal of John Wesley, ed. Nehemiah Curnock, I, London 1909, s. 108-50. - (16) Om betænkeligheder ved flytningen se Georgia Historical Quarterly, Savannah, marts 1969 , s. 83 og ror. - (17) De ubesmykkede beretninger er udgivet på engelsk af George F. Jones oversat efter originalerne i Halle: Samuel Urlsperger: Detailed Reports on the Salzburger Emigrants who settled in America, Iff, Atheus ${ }_{19} 68 \mathrm{ff}$ - (18) Tegningerne er genudgivet i facsimile i: Mark Catesby, The Natural History of Carolina, Florida and the Bahama Islands ..., I-II, Savannah 1974. - (19) Når dette er havnet her og ikke i Herrnhut-arkivet, kunne det tyde på, at det aldrig er blevet overleveret til adressaten. Brevet er i sig selv et interessant udtryk for tidens vulgarlatin. Oglethorpe har gjort sig gevaldig umage for at udtrykke sig i den samme bibelprægede, snirklede stil som Herrnhuterne. - (20) Trykt i oversattelse i tidsskriftet William and Mary Quarterly, Williamsburg, 1965, s. 319-33. 
(21) Jeg takker professor George F. Jones, Baltimore, for henvisning til dette brev og hjælp i andre sammenhænge. - (22) Ernst Ludwig vendte også tilbage til Europa i ${ }_{17} 73^{8}$ og blev senere officer i den hannoveranske hær, Georgia Historical Quarterly, Savannah 1969, s. 1 10. - (23) Charles Hudson: The Southeastern Indians, Tennessee, 1977. Se også John Wesley's forstehănds skildring af dem fra dec. $1737 \mathrm{i}$ The Journal of John Wesley (note ${ }_{15}$ ), I, s. 407-09. - (24) Flere af hans breve til the trustees i London er skrevet på fransk. - (25) To tegninger, nr. $3^{8}$ og 39 ses at være skåret ud af skitsebogen. Blandt de lose tegninger synes flere også at have siddet $\mathrm{i}$ bogen. De er i hvert fald pagineret sammen med bogens tegninger. - (26) Edith D. Johnston: Dr. William Houstoun, Savannah 1942, passim. Korrespondancen med Miller er bevaret $\mathrm{i}$ the Egmont Collection (Public Reccord Office, London), bl.a. instruksen til ham fra nov. 1735. - (27) I 1714 havde Catesby set cacao-plantager på Jamaica og noteret, at englanderne burde tage dette op i America. Catesby (note 18), bd. II, s. to6-07. - (28) Standardvarket om Uchi (Yuchi)indianerne er F. G. Speck: Ethnology of the Yuchi Indians, Anthropological Publication of the University of Pennsylvania Museum, vol. I, no. I, I9og. Men Speck lige sả lidt som senere forskere i samme emne har opdaget von Reck's gode beskrivelse fra 1736, nu oversat til engelsk i Georgia Historical Quarterly, Savannah 1963, s. 103-108. Også John Wesley skildrer dem i sin dagbog, I, s. 408. - (29) Schleswig-Holsteinisch Biographisches Lexicon, bd. 4, 1976, s. 193 . 